Arab World English Journal (AWEJ) Volume 12. Number1 March 2021

DOI: https://dx.doi.org/10.24093/awej/vol12no1.1

Pp. $3-18$

\title{
Is Foreign Language Teaching Possible Without School? Distance Learning Experiences of Foreign Language Students at Ataturk University During the Covid-19 Pandemic
}

\author{
Ebubekir Bozavlı \\ Department of Foreign Language \\ Faculty of Education \\ Ataturk University, Erzurum, Turkey \\ Email: ebozavli@atauni.edu.tr
}

Received: $12 / 19 / 2020$

Acceoted: 2/5/2021

Published: $3 / 24 / 2021$

\begin{abstract}
Covid-19 pandemic forced Turkey, like other countries, to give up face to face teaching in all educational institutions and to move toward distance education. This research aims to determine the learning experiences of foreign language students participating in distance education during the pandemic and their beliefs about whether it is possible to learn a foreign language without school. There were two problems that attempted to be answered; first, is it possible to learn a foreign language during and after the pandemic without being physically at school and second, what kinds of experiences do students gain in distance learning of foreign languages. The sample of the study consists of the students of department of foreign languages at Atatürk University, in Turkey. The study was carried out with a sample population composed of two hundred forty-two male and female students from German, French, and English Language Education Departments. A questionnaire consisting of thirteen close-ended questions created with a 5-Likert type developed by the researcher was applied. Participants answered the questionnaire online via Atatürk University Course Information System. The data were analyzed through the SPSS program to determine their frequency and descriptive analysis, and interpreted with content analysis and descriptive analysis. The results demonstrated that students believe that they can't learn a foreign language without going to school. Additionally, the findings indicated that their digital literacy skills are insufficient in distance teaching, and students show low motivation in learning.
\end{abstract}

Keywords: Covid-19 pandemic, de-schooling, digital literacy, distance learning, foreign language teaching, school, Turkey

Cite as: Bozavl1, E. (2021). Is Foreign Language Teaching Possible Without School? Distance Learning Experiences of Foreign Language Students at Ataturk University During the Covid-19 Pandemic.Arab World English Journal, 12 (1) 3-18.

DOI: https://dx.doi.org/10.24093/awej/vol12no1.1 


\section{Introduction}

One of the most important features that distinguish man from other living things on earth is that he needs education. As soon as animals are born, they instinctively find themselves adapted to their living environment in a concise time. It is food and protection they usually need during their early years of life. Whereas man finds its essence through education, and it takes years to be educated by other people who were previously educated. Education starts in the family and continues at school with childhood. Within each nation's principles, school systematically provides education to the citizens. The process that starts with pre-school education focuses on teaching in later classes.

One of the first examples of the school system in history emerged during the Sumerians. The invention and development of cuneiform started in the Sumerian schools, and some of the first written documents were clay tablets prepared for practice and study purposes (Aydin, 2012). The transformation of the school into a bureaucratic structure started with the developed western countries from the 18th century. This transformation took its place in the systems of other countries over time. Many countries adopted the philosophy of John Dewey in the early 1900s, and added his contemporary understanding to the concepts of school. Dewey (1932), led the schools of various countries to implement educational reforms by giving seminars in countries like China, Japan, Russia, and Turkey. According to Dewey, education is not a preparation for the future but a lifestyle. School should be life itself, should not be where only information is given, and habits are formed. School should be seen as a human community, and its function should be to contribute to the development of character, temper, and virtues that every child can realize. In this way, with its unique structure and rules, a school should be seen as a human community, a learning place, a social institution, an organization, a bureaucratic and legal institution based on a hierarchy of authority (Şişman, 2007).

Although traditionally, school is defined as the place where all kinds of education and training are carried out collectively, it is possible to see also different understandings of school. The most important of these understandings are the definitions of "effective school" and "learning school" that emerged from today's information society. The concept of an effective school is related to the quality of education provided in schools. Some schools are more successful than other schools among school types. Effectiveness is measured by the knowledge, skills, and competencies that the school offers to its students. Further, "the learning school" refers to the continuous flow of information. In such an atmosphere where knowledge changes in concise periods, individuals have to learn to learn. Likewise, school institutions have to turn into learning organizations. The learning school is a school where students are active and where "learning" rather than "teaching" is at the forefront. The learning school tries to realize the change and restructuring within itself to the extent permitted by the central system in which it is located. There is no distinction between teacher and learner in this system. All the actors are in the position of learners (Töremen, 2011).

In recent years, the school has been criticized by many experts for failing to fulfill requirements of the age we are in. According to the critics, the school does not make necessary and useful contributions to the learner. On the contrary, the school takes away many existing things such as curiosity, determination, motivation, etc. (Giordan, 1998). Children are curious when they start school. They want to learn everything. They are hungry for knowledge. They 
frequently ask questions to learn. By the age of 14-15, these children seem to despair, as if their lights are out. According to them, except for friendships, nothing in school is valuable. In their eyes, knowledge has lost its real value. They learn many formulas but do not know how they are used in daily life. Thus, the school becomes a worthless place for learners where only a diploma is awarded. (Giordan, 2002).

All these experienced lead individuals to seek different school conceptions or think of deschooling. Complaints and discomfort about traditional schools led both families and education authorities to seek new and alternative practices (Aydın, 2012). The concept of alternative school has been placed against the traditional school concept not only in underdeveloped or developing countries, and also in the United States. Alternative schools created with the name of "homeschools, Montessori schools, Waldorf schools, charter schools, small schools, magnet schools, paideia schools" have been seen as the solution to educational problems that cannot be overcome. While some of these schools are still valid today, some have lost their validity. Apart from these, the most interesting and destructive thought in schoolrelated minds is the idea of deschooling. This idea resembles homeschooling and similar models practiced in some American states. The most important advocates of this trend are Gatto (2018), and Illich (2018). Although they criticize the American public education system in their works, they generally object to the world public education system. Gatto, who has been a teacher in Manhattan for more than thirty years, identifies the education given at school with boredom. Gatto reveals this determination due to his observation of the students in the school and questioning them. The lessons for students are insignificant and mostly about what they already know. Instead of sitting on desks and listening to lectures, they want to deal with real things. This negative situation felt by the students is also reflected in the teachers. Many teachers experience a lack of enthusiasm, low energy, whining, complaints, and demoralization. Teachers state that students only focus on the grades they will receive. Gatto, continues his statements about the school as follows:

"Do we need a school? Of course, I do not mean education. I'm talking about compulsory education in schools. I'm talking about 12 years of compulsory education, six hours a day, five days a week, nine months a year. Is this tedious routine vital? A considerable number of Americans had not passed twelve years that we and our children passed through. But everything went well for them; Take George Washington, Benjamin Franklin, Thomas Jefferson, Abraham Lincoln. Sure, someone had taught them something, but the things they learned were not the product of the school. None had even finished secondary school. For most of American history, children generally did not attend high school, still those who were not in school were promoted to admirals like Farragut, inventors like Edison, industrial giants like Carnegie and Rockefeller, and writers like Melville and Twain" (2018, p.20).

Gatto thinks that the main purpose of modern public education consists of "aligning, integrating, defining and choosing" functions. The main goal of states is to make individuals as similar to education. In other words, it is to create a citizen profile that obeys the rules, can be restrained, submits, and does not create problems. Illich (2018), on the other hand, argues that the society as a whole should be de-schooled and that the school system leads to a monopoly in the distribution 
of opportunities rather than giving people equal opportunities. Many people acquire most of their knowledge outside of school. Students learn most of what they learn without teacher's help, or even despite the teachers. In reality, learning is a human activity that is least required to be directed by others. Most learning acts are not the result of teaching. Rather, this is a result of inheritance that is carried out without being prevented and with a meaningful approach. Therefore, de-schooling constitutes the basis of a movement that will lead to the emancipation of human beings. Really, the discourse of de-schooling of Gatto, and Illich seems to overturn or even destroy conventional social thought. No other perfect system to be placed in front of the public school system has yet to be discovered, and there are not enough individual or public resources to finance homeschooling and similar models. Hence the young people have to go to kindergarten and primary school. Besides, even most communities do not have the knowledge and experience to manage such an application without any problems.

However, de-schooling ideas seems applicable in certain disciplines such as foreign language learning and teaching, especially with adults. It is possible to learn a foreign language without a school, thanks to the development of technology, and the increase in the competence of today's individuals to use technology. As a matter of fact, some internet-based online applications and software have recently entered our lives in this field. For example, a Turkish foreign language student can learn online English, French, German, or any other language from a native speaker with active participation and interaction. Communications are carried out in mutual dialogues as in social life.

\section{The rationale of the study}

With the Covid-19 pandemic, the whole world was suddenly faced with Gatto and Illich's understanding of de-schooling education. Undoubtedly, if such a pandemic had not happened, no one would have witnessed a worldwide de-schooling society. In the spring of 2020, when the pandemic seriously threatened human health, almost all countries ended education in schools at all levels. After a short period of confusion, countries sought a solution to continue education without physically going to school. At this point, technology became a solution for humanity in the field of education. Thanks to the internet, lessons started to be given online. Houses turned into schools. Even formal education exams were conducted remotely online. The research aims to examine the experiences of students who participate in distance foreign languages learning during the Covid-19 pandemic and to determine whether they can learn a foreign language with technology without going to school. The understanding of teaching foreign languages without school is basically based on the principle of distance education. However, the principle of distance education does not question the existence of the school in general, nor ignores the school. Rather, it relates teaching to school. Face-to-face teaching and distance learning are complementary. However, the school has no place in distance foreign language teaching discussed in this study, and the idea is emphasized: "learners can learn a foreign language without ever going to school". It is thought that the study, which is original in this respect, will create a completely new and different perspective in minds.

\section{Research questions}

The study has been framed around the following questions.

1 - Is it possible to learn a foreign language without school during and after the pandemic? 
2- What kinds of experiences do students gain in distance teaching and learning of foreign languages during the pandemic?

\section{Literature Review}

When traditional learning is defined as face-to-face instruction provided by an instructor physically present in the classroom with students, distance learning is defined as "the acquisition of knowledge and skills through mediated information and instruction (Bollinger, 2017). Distance learning is a method of education in which the learner is physically separate from the teacher. It may be used on its own, or in conjunction with other forms of education, including face to face. In this approach, learners are physically separated from the institution that sponsors the instruction (Simonson, Smaldino \& Zvacek, 2015). In a general sense, distance learning mainly serves learners who cannot attend face-to-face courses or programs. Learners stay at home or office and follow the course, do the assignments, and interact with each other and the teacher via Internet (Ekmekçi, 2014). With a conventional understanding, distance learning is associated with the school. Face-to-face teaching and distance learning are complementary and supportive of each other. Distance learning in Turkey is carried out by some well-established universities in higher education. Anadolu University in 1982, Istanbul University and Atatürk University in 2010 are those that started distance learning. In primary and secondary education, the Ministry of National Education asynchronously have been supporting formal education with radio and television programs conducted through state channels since the 1980s. Due to the Covid-19 pandemic, by means of the Education Informatics Network (EBA) established in 2012, asynchronous and synchronous education is carried out during the period at all levels of school. Many public and private schools in Turkey have integrated distance teaching technology into training systems, and have made the students access to education through this technology.

The researches on distance learning concentrate generally on the philosophy of the method (Simonson et al. 2015), the theory (Moore, 1994) and the background (Simonson, 2013) and specifically on "foreign language anxiety, measuring oral proficiency (Lin \& Warschauer, 2015) effectiveness of this approach to teaching and learning in distance learning and importance, impact of distance education (Anglin \& Morrison, 2000; Simonson, 2002). Simonson et al. (2015) state that distance education is the best way to learn because it allows students to acquire knowledge when it is most relevant to them. Peters (1993) emphasizes student effectiveness in distance learning and supposes that the students assume more responsibility for his or her own learning than is possible in face-to-face situations. Another study conducted on learning motivations of students learning English by means of distance education (Fandino, Munoz \& Velandia, 2019) alleges that students are strongly influenced by external factors. In addition, the relevant literature suggests works on distance learning curriculum, course syllabi and course activities. One of these researches is (K1lıçkaya, Krajka \& Latoch-Zielinska, 2014), in which different models of distance learning courses and reflecting on their applicability for English language teaching in Turkey. Even though some of modes of learning at a distance might not be compatible with cultural conditions of Turkish students, the versatility of contemporary Learning Management Systems enables instructors to design their courses in such a way to address culturally conditioned preferences. As for the activities, O, Down (2007) reached that the use of online communicative activities gives learners more opportunities to interact together than would be possible within the time constraints of the traditional classroom. 


\section{Method}

\section{Research Design}

The research has a quantitative value in terms of percentage and frequency, and it also has a qualitative value when interpreting it with the descriptive research (Yıldırım \& Şimşek, 2000; Giroux \& Tremblay, 2002).

\section{Participants}

The sample consists of the students of Foreign Languages Department at Atatürk University. The study was carried out with a sample population composed of two hundred forty-two male and female students from German, French, and English Language Education Departments. Statistics about the sample are given in Table one.

Table 1. Percentages and Frequencies Regarding Gender

\begin{tabular}{llcc}
\hline & & \multicolumn{2}{c}{ Students } \\
\hline \multirow{2}{*}{ Gender } & & $\%$ & $\mathrm{~N}$ \\
\hline \multirow{3}{*}{ Departments of Education } & Woman & 78,5 & 190 \\
& Man & 21,5 & 52 \\
\hline \multirow{3}{*}{ Grade Levels } & English Language Teaching & 38,8 & 94 \\
& French Language Teaching & 16,5 & 40 \\
& German Language Teaching & 44,6 & 108 \\
& Preparatory Class & 26,4 & 64 \\
& 1st Grade & 29,8 & 72 \\
& 2nd Grade & 14,0 & 34 \\
& 3rd Grade & 16,1 & 39 \\
\hline
\end{tabular}

A total of 242 people, 190 women (78.5\%) and 52 men (21.5\%), participated in the study. 94 of the participants $(38.8 \%)$ are English Language Education, $40(16.5 \%)$ are French Language Education, 108 (44.6\%) are German Language Education students. 64 of the participants $(26,4 \%)$ are in Prep, $72(29,8 \%)$ are in 1st grade, $34(14,0 \%)$ are in 2nd grade, $39(16,1 \%)$ are in 3rd grade., $33(13,6 \%)$ are 4 th grade students.

\section{Research Instrument}

A questionnaire consisting of thirteen closed-ended questions created with a 5-Likert Type developed by the researcher was applied. Participants answered the questionnaire via Distance Learning Information System of Atatürk University.

\section{Data Analysis}

SPSS Program Assistance was used to manage the data. The subsequent analysis is by identifying questions and analysis of frequency distribution. Data were interpreted with content analysis, and descriptive analysis among qualitative research methods.

\section{Findings}

The findings obtained from the questionnaire are presented in the tables below.

Table 2. Technological tools students use in distance teaching

$$
\text { Frequency Percentage }
$$


Arab World English Journal (AWEJ) Volume 12. Number 1. March 2021

Is Foreign Language Teaching Possible Without School?

Bozavl1

\begin{tabular}{lcc}
\hline Smartphones & 76 & 31,4 \\
Personal Computer & 68 & 28,1 \\
Common desktop computer in the home & 18 & 7,4 \\
Tablet & 8 & 3,3 \\
Smartphones and Personal Computer & 72 & 29,8 \\
Other & &
\end{tabular}

As seen in Table two, 31.4\% of the students attend online classes with smartphones, $28.1 \%$ with personal computers, and $29.8 \%$ with both smartphones and personal computers. These results show that approximately $90 \%$ of the students have a technological device of their own.

Table 3. The ways students connect to distance lessons

Frequency Percentage

\begin{tabular}{lcc}
\hline I don't have internet access at home, I can't connect. & 16 & 6,6 \\
$\begin{array}{l}\text { I do not have my internet at home; I use the internet } \\
\text { of my family members. }\end{array}$ & 4 & 1,7 \\
$\begin{array}{l}\text { I do not have internet access at home; I connect } \\
\text { outside of the home (internet cafe etc.) }\end{array}$ & 2 &, 8 \\
I connect with my phone at home. & 26 & 10,7 \\
I connect via Wi-Fi at home. & 170 & 70,2 \\
I connect with my phone and Wi-Fi at home & 24 & 9,9
\end{tabular}

Table three reveals that $70.2 \%$ of the students attend the classes with $\mathrm{Wi}-\mathrm{Fi}$ at home, $10.7 \%$ with the internet of their phones, and 9.9\% with both Wi-Fi and the internet of their phones. Also, the findings reveal that there are students who want to attend online classes but cannot because they do not have an internet.

Table 4. Students' perceptions of school in distance foreign languages learning

\begin{tabular}{|c|c|c|c|c|c|}
\hline Hypotheses & & Frequency & Percentage & $\begin{array}{c}\text { Valid } \\
\text { Percent }\end{array}$ & $\begin{array}{c}\text { Cumulative } \\
\text { Percent }\end{array}$ \\
\hline There is no need for a school to & Strongly Disagree & 98 & 40,5 & 40,5 & 40,5 \\
\hline learn a foreign language. & Disagree & 88 & 36,4 & 36,4 & 76,9 \\
\hline A foreign language can be & Undecided & 34 & 14,0 & 14,0 & 90,9 \\
\hline learned through distance & Agree & 12 & 5,0 & 5,0 & 95,9 \\
\hline education. & Strongly Agree & 10 & 4,1 & 4,1 & 100,0 \\
\hline I can improve my listening and & Strongly Disagree & 74 & 30,6 & 30,6 & 30,6 \\
\hline speaking skills in foreign & Disagree & 102 & 42,1 & 42,1 & 72,7 \\
\hline languages through distance & Undecided & 34 & 14,0 & 14,0 & 86,8 \\
\hline learning without going to school. & Agree & 24 & 9,9 & 9,9 & 96,7 \\
\hline
\end{tabular}


Table four shows the results of the frequency test. They are related to students' school perceptions in distance learning of foreign languages. $76.9 \%$ of the students think that foreign language education is impossible without school. The mean rate of this item suggests a low value, as seen in table seven $($ mean $=1,9587, \mathrm{st}=1,05765)$. Only $9.1 \%$ of the students agree with this idea. The rate of those who think that listening and speaking skills can be improved online without going to school is $12.2 \%$. $72.7 \%$ of the students believe that these skills can only be developed at school. It is seen that the percentage in the second item (72.7\%) is partially lower than the rate in the first item (76.9\%). The difference between two items reveals that basic skills in a foreign language can be taught independently. Students seem more dependent on school for teaching grammar, reading, and writing skills.

It is determined that the school's limits are exceeded, even if a little, in the teaching of listening and speaking skills. This situation can be associated with the development of technology, and the naturalness of verbal communication. Individuals learn to speak in their mother tongue in social situations outside of school. Nowadays, verbal communication is quickly done as audio-visual with technological tools such as "zoom, Skype, WhatsApp" regardless of distance. On the other hand, foreign language students can access audio-visual materials more quickly with technology than previous years.

Table 5. Distance learning experiences of students in foreign languages

\begin{tabular}{llcccc}
\hline Hypotheses & & Frequency & Percentage & Valid Percent & $\begin{array}{c}\text { Cumulative } \\
\text { Percen }\end{array}$ \\
\hline This is the first time I've had the & Strongly Disagree & 10 & 4,1 & 4,1 & 4,1 \\
experience of distance foreign & Disagree & 18 & 7,4 & 7,4 & 11,6 \\
language learning & Undecided & - & - & - & - \\
& Agree & 108 & 44,6 & 44,6 & 56,2 \\
& Strongly Agree & 106 & 43,8 & 43,8 & 100,0 \\
\hline I am having technical problems in & Strongly Disagree & 10 & 4,1 & 4,1 & 4,1 \\
foreign language virtual & Disagree & 68 & 28,1 & 28,1 & 32,2 \\
classroom applications. & Undecided & 18 & 7,4 & 7,4 & 39,7 \\
& Agree & 108 & 44,6 & 44,6 & 84,3 \\
& Strongly Agree & 38 & 15,7 & 15,7 & 100,0 \\
\hline I think distance foreign language & Strongly Disagree & 90 & 37,2 & 37,2 & 37,2 \\
teaching with virtual classes is & Disagree & 88 & 36,4 & 36,4 & 73,6 \\
fruitful. & Undecided & 32 & 13,2 & 13,2 & 86,8 \\
& Agree & 24 & 9,9 & 9,9 & 96,7 \\
& Strongly Agree & 8 & 3,3 & 3,3 & 100,0 \\
\hline I know how to use foreign & Strongly Disagree & 8 & 3,3 & 3,3 & 3,3 \\
language virtual classroom & Disagree & 14 & 5,8 & 5,8 & 9,1 \\
applications. & Undecided & 22 & 9,1 & 9,1 & 18,2 \\
& Agree & 138 & 57,0 & 57,0 & 75,2 \\
& Strongly Agree & 60 & 24,8 & 24,8 & 100,0 \\
\hline
\end{tabular}

As seen in Table five, $88.4 \%$ of the students experience distance learning foreign languages for the first time. It is also understood that $60.3 \%$ of the students have technical problems attending the lessons, and $32.2 \%$ do not have any connection problems. The majority of the participants (73.6\%) think distance foreign language teaching is not fruitful. The rate of those who are satisfied from distance education is only $13.2 \%$. 
Arab World English Journal (AWEJ) Volume 12. Number 1. March 2021

Is Foreign Language Teaching Possible Without School?

Bozavl1

Table 6. Students' perceptions and competencies in distance foreign languages learning

\begin{tabular}{|c|c|c|c|c|c|}
\hline \multicolumn{2}{|l|}{ Hypotheses } & Frequency & Percent & $\begin{array}{c}\text { Valid } \\
\text { Percent }\end{array}$ & $\begin{array}{c}\text { Cumulative } \\
\text { Percent }\end{array}$ \\
\hline \multirow{5}{*}{$\begin{array}{l}\text { I enjoy distance foreign } \\
\text { language learning }\end{array}$} & Strongly Disagree & 82 & 33,9 & 33,9 & 33,9 \\
\hline & Disagree & 92 & 38,8 & 38,8 & 71,9 \\
\hline & Undecided & 32 & 13,2 & 13,2 & 85,1 \\
\hline & Agree & 24 & 9,9 & 9,9 & 95,0 \\
\hline & Strongly Agree & 12 & 5,0 & 5,0 & 100,0 \\
\hline \multirow{5}{*}{$\begin{array}{l}\text { During distance foreign } \\
\text { language learning, I spend less } \\
\text { time studying than I do at } \\
\text { school }\end{array}$} & Strongly Disagree & 12 & 5,0 & 5,0 & 5,0 \\
\hline & Disagree & 52 & 21,5 & 21,5 & 26,4 \\
\hline & Undecided & 34 & 14,0 & 14,0 & 40,5 \\
\hline & Agree & 100 & 41,3 & 41,3 & 81,8 \\
\hline & Strongly Agree & 44 & 18,2 & 18,2 & 100,0 \\
\hline \multirow{5}{*}{$\begin{array}{l}\text { Distance foreign language } \\
\text { learning reduces my motivation } \\
\text { to learn }\end{array}$} & Strongly Disagree & 20 & 8,3 & 8,3 & 8,3 \\
\hline & Disagree & 32 & 13,2 & 13,2 & 21,5 \\
\hline & Undecided & 26 & 10,7 & 10,7 & 32,2 \\
\hline & Agree & 94 & 38,8 & 38,8 & 71,1 \\
\hline & Strongly Agree & 70 & 28,9 & 28,9 & 100,0 \\
\hline \multirow{5}{*}{$\begin{array}{l}\text { Distance foreign language } \\
\text { learning dulls my capacity to } \\
\text { learn foreign languages. }\end{array}$} & Strongly Disagree & 12 & 5,0 & 5,0 & 5,0 \\
\hline & Disagree & 44 & 18,2 & 18,2 & 23,1 \\
\hline & Undecided & 34 & 14,0 & 14,0 & 37,2 \\
\hline & Agree & 106 & 43,8 & 43,8 & 81,0 \\
\hline & Strongly Agree & 46 & 19,0 & 19,0 & 100 \\
\hline \multirow{5}{*}{$\begin{array}{l}\text { I understand and learn the } \\
\text { lessons given in distance } \\
\text { foreign language learning. }\end{array}$} & Strongly Disagree & 24 & 9,9 & 9,9 & 9,9 \\
\hline & Disagree & 76 & 31,4 & 31,4 & 41,3 \\
\hline & Undecided & 100 & 41,3 & 41,3 & 82,6 \\
\hline & Agree & 34 & 14,0 & 14,0 & 96,7 \\
\hline & Strongly Agree & 8 & 3,3 & 3,3 & 96,7 \\
\hline \multirow{5}{*}{$\begin{array}{l}\text { Distance foreign language } \\
\text { teaching negatively affects my } \\
\text { socialization. }\end{array}$} & Strongly Disagree & 16 & 6,6 & 6,6 & 6,6 \\
\hline & Disagree & 66 & 27,3 & 27,3 & 33,9 \\
\hline & Undecided & 32 & 13,2 & 13,2 & 47,1 \\
\hline & Agree & 84 & 34,7 & 34,7 & 81,8 \\
\hline & Strongly Agree & 44 & 18,2 & 18,2 & 100,0 \\
\hline \multirow{5}{*}{$\begin{array}{l}\text { I have sufficient self-control in } \\
\text { distance foreign language } \\
\text { learning. I know my } \\
\text { responsibilities. }\end{array}$} & Strongly Disagree & 8 & 3,3 & 3,3 & 3,3 \\
\hline & Disagree & 46 & 19,0 & 19,0 & 22,3 \\
\hline & Undecided & 64 & 26,4 & 26,4 & 48,8 \\
\hline & Agree & 88 & 36,4 & 36,4 & 85,1 \\
\hline & Strongly Agree & 36 & 14,9 & 14,9 & 100,0 \\
\hline
\end{tabular}

According to the data in Table six, $72.7 \%$ of the students (mean $=2,1405$, st $=1,14004)$ do not like distance foreign language teaching, 59.5\% of them study less than face-to-face teaching during distance learning. While $67.7 \%$ of the students have motivation problems, $62.8 \%$ of the students (mean $=3,5372$, st $=1,13811$ ) have their foreign language learning capacities dulled with distance education. $17.3 \%$ of the students state that they understand the online lessons, and $41.3 \%$ state that they do not understand the lessons. Almost half of the students (41.3\%) do not know whether they learn in online classes or not. On the other hand, 52.9\% of the students think that distance teaching harms their socialization.

Students study less than usual time, have motivation problems, and do not like online teaching. They believe that their learning capacity is reduced because lessons are inefficient. Also they do not know whether they learn in lessons or not. This situation can be linked to the inadequacy of their soft technology skills. While "hard" technologies consist of electronic mail, 
teleconferencing, fax, video conferencing and other electronic means of facilitating communication, soft skills have been defined by various authors as personal characteristics such as: work ethics, positive attitude, social grace, facility with language, friendliness, integrity and the willingness to learn (Harris \& Rogers, 2008). Technologies are not equally malleable. They can be softer (implying greater malleability) or harder (implying less flexibility). Softer technologies require more effort, are less consistent, and are mostly slower to produce results than harder technologies, but they offer greater flexibility an opportunity for creativity, innovation and change (Dron, 2014).

\section{Discussion}

Through the analysis of the questionnaire, the findings demonstrate that foreign language students prefer face-to-face learning in school and classroom interaction more than distance learning. This result shows similarity with the findings of some scholars in Turkey and in other countries. The opinion of foreign language students about the school engaging in higher education at the University can also be seen in students at the secondary level in Turkey. It was determined that the highest arithmetic averages of the secondary school students in their attitudes towards school are as follows: "loving to go to school and being in school", "thinking that school is an important social structure" and "believing that there will be no society without schools (Adigüzel \& Karadaş, 2013). It is possible to encounter similar results in distance education at the international level during the pandemic period. For example, $70.1 \%$ of Greek university students show their preferences for traditional face-to-face teaching (Charissi, Tympa \& Karavida, 2020). Similary, Al-Nofaie (2020) observed, in his article investigated the perceptions of Saudi University students towards distance learning, that they favored traditional in-class learning. Similar studies were conducted by Erdoğan, 2020; Maican \& Cocorada, 2020). Erdogan's research on English preparatory class students concluded that Turkish students do not like learning English remotely because they do not find it useful, and they enjoy face-to-face learning more. Maican and Cocorada's research with Romanian language students also reveals that students think that going to school to learn a foreign language is the best method, and that the school will still maintain its importance after the pandemic. Although it is rare, it is possible to see studies reaching a different conclusion from these results. For example one of these studies (Fansury, Januarty \& Syawal, 2020) alleges the advantages of using digital platforms learning English during the Covid-19 pandemic, having a positive effect on student motivation, giving authentic cultural information, exposing students to real language. Researchers associate these positive attitudes of Indonesian students with their being millennial generation, and excessive interest in technology.

Although students think differently, the idea of a de-schooling society seems to be an appropriate approach to language learning, especially to mother tongue acquisition. From the moment of birth, the child acquires the spoken language in a short period of two years in the society, without any linguistic background and experience and without the need for any experienced instructor. The child neither attends a school nor follows a method while learning the language. The child also does not have an unlimited number of resources. There are only individuals around the child who speak the native language. In this way, he learns to speak. Language acquisition occurs due to the child's cognitive features and environmental influences. In other words, the child has an innate ability to learn to speak and must be in a social environment. The child hears what is said around his for a certain period and collects what he 
hears in his memory for later use. With his physiological and physical development, hearing what is spoken in the social environment is like an exercise phase for the child. Although he cannot produce the sounds of language, he perceives, internalizes and separates them from each other. In this way, the phenomenon of understanding is formed before production. In the natural environment, every person can quickly learn and speak their mother tongue.

There are two situations in foreign language learning. In the first, there is a natural environment with native speakers of the language, while in the second; there is a learning environment in institutions. In other words, in an unnatural environment like school, there are no speakers of that language. Learning and teaching a foreign language in an unnatural environment often arises. Many entrepreneurs demonstrate innovative thinking, and approach to eliminate this learning problem. One of these approaches aims to create a foreign language learning space in an unnatural environment where there is no school (Dergisi, 2019). Pioneers of this idea argue that language is learned in social environments, not in schools. They are against the idea of school in the usual sense. In these businesses called "language cafes", people can improve their language as if they live abroad. Native English or French instructors work in these cafes, and they practice with individuals who want to improve their speaking skills. It is strictly forbidden to speak the mother tongue in such a social environment. An ambience is created through various games, activities, and movie watching and discussion activities. Participants can join conversation groups appropriate to their language level. Most importantly, there is no exam in such a learning environment. Participants are not subjected to any examination at the end of a certain education period. Entrepreneurs aim to contribute to Turkey's problems about learning a foreign language with branches they open in different regions. Because, learning foreign language is still a major problem as a developing country in Turkey. There are no social environments where the foreign language learned sociologically is spoken.

At the end of the foreign language education, which starts in the second grade of primary school at an early age and continues until the university's end, the learners fail to express themselves even at a basic level. After thousands of hours of teaching, learners are generally able to understand what they read, answer questions in exercise books, apply grammar rules on paper, but cannot speak. The failure of learners' verbal comprehension and expression capacity is due to the fact that foreign language teaching at school is grammatically based and teacher-centered. The teacher tells the grammar rules in the classroom, explains the meaning of the words, reads and translates the texts. Most importantly, the teacher does not use the foreign language effectively and communicates with the learners in their native language. English Proficiency Index, which aims to determine the international foreign language proficiency of countries, reveals that Turkey's level of English proficiency is very shallow, and Turkey takes place at the end of the success ranking (Bozavl1, 2017). For example, Turkey was ranked 41st among 60 countries in 2013, 47th among 63 countries in 2014, and 50th among 70 countries in 2015. 73rd among 88 countries in 2018, and 79th among 100 countries in 2019. The name of Turkey is mostly mentioned together with the countries such as Iraq, Azerbaijan and Venezuela, which are underdeveloped or developing countries. Unfortunately, over the years, the country's level of English remains very low. The country rank falls to a lower rank every year.

Despite this failure, it seems a paradox in the present study that the participants thought learning a foreign language would not be possible without school. Participants still trust and believe in the school in learning foreign languages. Participants' beliefs about the school may be Arab World English Journal www.awej.org 13 
associated with social perception and social realities in the field of education in Turkey. Foreign language students must attend school and have a diploma to find a job. Socially, parents and, people live in continue to attribute a positive value to the school. Parents encourage their children to go to school and learn there. For students, school is important because they don't know how to use the technology in autonomous learning. However, humanity is evolving into a digital universe. Internet technology and humanoid robots seem to shape foreign language learning as in other learning areas. In the coming years, there will probably not be a foreign language class as we know and, also foreign language teachers. People will improve the language learned by speaking to native speakers online. Maybe each of them will have a humanoid robot speaking a foreign language or languages. Such robots are available today (Haydée, 2019), (Hoyau \& Dechambenoy, 2015), (Liao, 2018). One of the most popular robots used in foreign language teaching and learning is Nao. This robot developed by SoftBank is used in sales, finance, public service, health, tourism, education and research. It can communicate verbally using gestures and even facial expressions. Nao was further developed by Finland, and this new model was described as the first social robot powered by artificial intelligence to help individuals learn foreign languages. While Nao is an ordinary robot, this robot understands the needs of students and, in a fun way, allows them to develop their verbal expression skills without fear of making mistakes. Undoubtedly, the future will spread such robots.

In recent years, the development of artificial intelligence has led to changes in the perception of foreign languages and the methods used in teaching foreign languages. GodwinJones states (2009)that three different scenarios stand out in foreign languages within the framework of technological developments. The first of these scenarios is that there is no longer a need to learn a foreign language because communication in a foreign language will take place with technological devices, human influence will remain in the background and a device will instantly transfer conversations between people from one language to another. The second scenario suggests that foreign language learning is needed, but the learning method is different. Foreign language will not be taught in educational institutions with a proper understanding and, it will be learned informally, just like native language acquisition. The last scenario is about learning a foreign language both formally and informally. The second reminds of the understanding of de-schooling foreign language learning, which is the subject of this study. Those who learn through autonomous learning will understand the foreign language they want to learn online without the need for a school. Undoubtedly, this type of learning method requires learners to have some competencies. Learners should have a developed sense of responsibility, self-control, questioning, interpreting, and testing their learning, making decisions, implementing and self-orientation. Because they no longer have planning, timing, and evaluation system as they find ready at school. Learners themselves must create all of these systems. It can be easily observed that these skills are not yet developed in today's foreign language students. As Fu (2020) stated, the crises during the Covid-19 pandemic can provide learners with essential skills. Just as learners acquire some basic habits in face-to-face teaching over time, they will also gain some habits in distance teaching. The important thing is to know how to turn the crisis into an opportunity. Those who achieve this will gain in their education, those who fail will lag behind others. Daniel (2020) thinks that returning to daily life will not be simple at the end of the Covid19 pandemic, and that educational institutions can adopt different understandings in methods and techniques when they start face-to-face teaching in classrooms or campuses. 


\section{Conclusion}

The present study is to reveal the learning experiences of students who participate in distance foreign language learning during the Covid-19 pandemic, and to determine whether they can learn a foreign language with technology without going to school. The current study is limited to a small sample of learners from Atatürk University in Turkey. The findings reveal that the students think that it is not possible to learn a foreign language without school and that also listening and speaking skills in a foreign language cannot be improved online. Additionally, they do not believe that distance foreign language learning is fruitful. The findings of the study also show that the students experience distance foreign language learning for the first time and the vast majority of students show low motivation in learning, do not seem satisfied with distance learning and think lessons are inefficient, have problems in evaluating what they have learned, and spare less time than face-to-face learning. In addition, the students do not like distance foreign language learning because the model harms their socialization. Moreover, digital literacy training for foreign language students is insufficient. Distance learning in higher education will probably become more common. Institutions will pursue a technology-based education systematically, as they think it will be more useful than face-to-face education.

\section{About the Author:}

Ebubekir Bozavlı is an Associate Professor Doctor in the Department of Foreign Languages Department at Kazım Karabekir Faculty of Education Ataturk University in Erzurum, Turkey. The author has several national and international publications. His research interests include foreign language learning and teaching, early foreign language learning, linguistics, psycholinguistics. ORCID ID: https://orcid.org/0000-0002-4475-5777

\section{References}

Adıgüzel, A., \& Karadaş, H. (2013). Ortaöğretim Öğrencilerinin Okula İlişkin Tutumlarının Devamsızlık ve Okul Başarıları Arasındaki İlişki. YYU Journal of Education Faculty, 10 (1), 49-66.

Al-Nofaie, H. (2020). Saudi University Students' perceptions towards Virtual Education During Covid-19 Pandemic: A case Study of Language Learning via Blackboard. Arab World English Journal, 11 (3) 4-20. DOI: https://dx.doi.org/10.24093/awj/vol11no3.1

Anglin, G., \& Morrison, G. (2000). An analysis of distance education research: Implications for the instructional technologist. Quarterly review of Distance Education, 1(3), 189-194.

Aydın, İ. (2012). Alternatif Okullar. Ankara: Pegem Akademi.

Bollinger, A. S., (2017). Foreign Language Anxiety in Traditional and Distance Learning Foreign Language Classrooms. A Dissertation presented in partial fulfillment of the requirements for the degree doctor of Education. Liberty University.

Bozavlı, E. (2017). Yabancı Dil Öğretiminde Sözel İletişim, Türkiye ve Avrupa Ülkelerindeki Görünüm. Incluisive Education: Ensuring Quality Education To All Learners. Çanakkale: Ulead Annual Congress.

Charissi, A., Tympa, E., \& Karavida, V. (2020). Impact of the covid-19 disruption on university students' perceptions and behavior. European Journal of Education Studies. 7(11). DOI: 10.46827/ejes.v7i11.3348 
Daniel, S.J. (2020). Education and The Covid-19 Pandemic. Prospects: 49, 91-96 https://doi.org/10.1007/s11125-020-09464-3.

Dergisi, P. (2019). Haftalık Ekonomi Dergisi, 45. Sayı, İstanbul: Turkuaz Medya Yayınc1lı.

Dewey, J. (1932). The School and Society. London: The Cambridge University Press.

Dron, J. (2014). Innovation and Change: changing how we change. In O. Zawacki-Richter, \& T. Anderson, (eds), Online Distance Education, Towards a Research Agenda AU Press: Athabasca University.

Ekmekçi, E. (2014). Distance education in foreign language teaching: evaluations from the perspectives of freshman students. Procedia- Social and Behavioral Sciences, 176, 390397.

Erdoğan, Ş.K. (2020). Foreign Language Education During Covid- 19 Pandemic: An Evaluation From the Perspectives of Preparatory Class Students. Milli Eğitim, 49 (1), 1079-1090.

Fandino, F. G. E., Munoz, L. D. \& Velandia, A. G. S. (2019). Motivation and E-Learning English as a foreign language: A quatative study. Heliyon, 5.

Fansury, A. H., Januarty, R., \& Syawali A. W.R. (2020). Digital Content For Millennial Generations: Teaching The English Foreign Language Learner On Covid-19 Pandemic. Journal of Southwest Jiaotong University, 55 (3). DOI: 10.35741/issn.0258-2724.55.3.40

$\mathrm{Fu}, \mathrm{H}$. (2020). Implementing online ELT in the time of crisis: ordeal or opportunity? ELT Journal 74(3), 354-348. Doi:10.1093/elt/ccaa030.

Gatto, J.T. (2018). Çev. Özkan, M. A. Eğitim: Bir Kitle İmha Silahı, Zorunlu Eğitimin Karanlık Dünyasında Bir Yolculuk. (Weapons of Mass Instruction: A Schoolteacher's Journey Through the Dark World of Compulsory Schooling) İstanbul: Edam Yayınları.

Giordan, A. (1998). Apprendre. Paris: Editions Belin.

Giordan, A. (2002). Une autre école pour nos enfants? (Another school for children ?) Paris: Delagrave.

Giroux, S., \& Tremblay, G. (2002). Méthodologie Des Sciences Humaines, La Recherche en Action. Québec: Editions du Renouveau Pédagogique.

Godwin-Jones, R. (2019). In a World of SMART Technology, Why Learn Another Language? Educational Technology \& Society. Tome: 22(2). Pp: 4-13.

Haydée S, (2019). Apprentissage des langues, jeu et robotique - Le projet Ludibot», Alsic 22(1) Available at URL : http://journals.openedition.org/alsic/3848.

Harris, K.S., \& Rogers, G. E. (2008). Soft skills in the technology education classroom: What do students need? The Technology Teacher. 68(3), 19-24

Hoyau, E., \& Dechambenoy, L. (2015). Téléprésence télé-opérée: Robot LycéenRapport du travail de recherche dans le cadre du cours d'IAVIAC. France: Available at https://www.researchgate.net/profile/Gerard_Bailly/publication/278625871_Cognition_Aff ects_et_Interaction/links/562e3c7108aef25a24442d21.pdf\#page=47

Illıch, I. (2018). Çev. Özay. M. Okulsuz Toplum. (Deschooling Society) İstanbul: Şule Yayınları. 
Kılıçkaya, F., Krajka, J., Latoch-Zielinska, M. (2014). E-learning in Foreign Language Instruction in Turkey: Curriculum Models and Course Design Guidelines. Uşak Üniversitesi Sosyal Bilimler Dergisi. 7(3).

Liao, J. (2018). Exploring the affordances of telepresence robotsin foreign language learning. Language Learning \& Technology 22 (3), 20-32.

Lin, C.H., \& Warschauer, M. (2015). Online Foreing Language Education: What are the Proficiency Outcomes? The Modern Language Journal, 99 (2), 394-397.

Maican, M.A., \& Cocorada, E. (2020). Online Foreign Language Learning in Higher Education and Its Correlates during the Covid-19 Pandemic. Sustainability, 13 (781).

Moore, M. (1994). Autonomy and interdependence. The Amerikan Journal of Distance Education. 8(2), 1-5.

O'Dowd, R. (2007). Foreign language education and the rise of online communication: A review of promises and realities. In R. O'Dowd (Ed.), Online intercultural exchange: An introduction for foreign language teachers (pp. 17-37). Clevedon: Multilingual Matters.

Peter, O. (2001). Understanding distance education. In K. Harry., M. John., \& D. Keegan (Ed.) Distance Education, New Perspectives (pp. 11-18 ). London: Routledge Falmer.

Simonson, M. (2002). In case you are asked: effectiveness of distance education. Quarterly Review of distance education, 3 (4).

Simonson, M. (2013). Distance education: Statewide, institutional and international applications. Charlotte: Information Age.

Simonson, M., Smaldino, S., Zvacek, S. (2015). Teaching and Learning at A Distance. Foundations of Distance Education. The United States of America: Information Age Publishing.

Şişman, M. (2007). Eğitimde Demokrasi ve Sosyal Adalet: Türkiye Eğitim Sisteminin Değişmeyen Miti. Ankara: Türk Eğitim Sisteminde Yeni Paradigma Arayışları Sempozyumu Bildiri Kitabı. Pozitif Matbaacılık.

Töremen, F. (2011). Öğrenen Okul. Ankara: Nobel Yayınları.

Yıldırım, A.\& Şimşek,H. (2000). Sosyal Bilimlerde Nitel Araştırma Yöntemleri. Ankara: Seçkin Yayıncilik.

\section{Appendix}

Table 7. Students' overall level of agreement/disagreement

\begin{tabular}{|c|c|c|c|c|c|c|c|}
\hline Questions & $\begin{array}{l}\text { Strongly } \\
\text { Disagree }\end{array}$ & Disagree & Undecided & Agree & $\begin{array}{l}\text { Strongly } \\
\text { Agree }\end{array}$ & Mean & Indicator \\
\hline $\begin{array}{l}\text { Q1. I think there is no need for a } \\
\text { school to learn a foreign language. A } \\
\text { foreign language can be learned } \\
\text { through distance education. }\end{array}$ & $40,5 \%$ & $36,4 \%$ & $14 \%$ & $5 \%$ & $4,1 \%$ & 1,95 & Disagree \\
\hline $\begin{array}{l}\text { Q2. I can improve my listening and } \\
\text { speaking skills in foreign languages } \\
\text { through distance learning without }\end{array}$ & $30,6 \%$ & $42,1 \%$ & $14 \%$ & $9,9 \%$ & $3,3 \%$ & 2,13 & Disagree \\
\hline
\end{tabular}

ISSN: 2229-9327 
going to school.

Q3. Distance teaching of foreign languages reduces my motivation to learn.

\begin{tabular}{|c|c|c|c|c|c|c|}
\hline $8,3 \%$ & $13,2 \%$ & $10,7 \%$ & $38,8 \%$ & $28,9 \%$ & 3,66 & Agree \\
\hline $3,3 \%$ & $19,0 \%$ & $26,4 \%$ & $36,4 \%$ & $14,9 \%$ & 3,40 & Agree \\
\hline $3,3 \%$ & $5,8 \%$ & $9,1 \%$ & $57,0 \%$ & $24,8 \%$ & 3,94 & Agree \\
\hline $4,1 \%$ & $28,1 \%$ & $7,4 \%$ & $44,6 \%$ & $15,7 \%$ & 3,39 & Agree \\
\hline $4,1 \%$ & $7,4 \%$ & $0 \%$ & $44,6 \%$ & $43,8 \%$ & 4,16 & Agree \\
\hline $37,2 \%$ & $36,4 \%$ & $13,2 \%$ & $9,9 \%$ & $3,3 \%$ & 2.05 & Disagree \\
\hline $33,9 \%$ & $38,8 \%$ & $13,2 \%$ & $9,9 \%$ & $5,0 \%$ & 2,14 & Disagree \\
\hline
\end{tabular}

Q4. I have sufficient self-control in distance learning foreign languages. I know my responsibilities.

Q5. I know how to use foreign language virtual classroom applications.

Q6. I am having technical problems in foreign language virtual classroom applications.

Q7. This is the first time I've had the experience of distance foreign language learning

Q8. I think distance foreign language teaching with virtual classes is fruitful.

Q9. I enjoy distance foreign language learning

Q10. Distance foreign language teaching negatively affects my socialization.

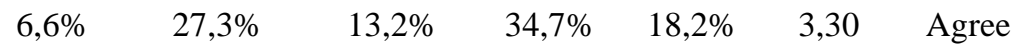

Q11. I understand and learn the lessons given in distance foreign language learning.

Q12. During distance foreign language learning, I spend less time studying than I do at school

$5,0 \% \quad 21,5 \% \quad 14,0 \% \quad 41,3 \% \quad 18,2 \% \quad 3,46 \quad$ Agree

Q13. Distance foreign language learning dulls my capacity to learn foreign languages.

$5,0 \% \quad 18,2 \% \quad 14,0 \% \quad 43,8 \% \quad 19,0 \% \quad 3,53 \quad$ Agree

Note: Mean score was used to determine students' overall level of agreement/disagreement 